\section{Taking the skeleton out of the cupboard}

\section{Peter Sheterline}

The Cytoskeleton: An Introductory Survey. By Manfred Schliwa. SpringerVerlag:1986. Pp.326. DM 172.

A DECADE or more of enthusiastic research on the structure of the cytoplasmic compartment in eukaryotic cells has been based on the premise that therein lies the apparatus by which the motile, morphological and polarized attributes of cells are defined. From such studies has emerged the principle that these organizational activities reside primarily in the dynamic behaviour of an integrated network of protein polymers, and their interactions with other structures in the cell. There lingers, however, a divisive and loosely applied terminology where "cytosol" is used to describe aspects of the cytoplasm in a metabolic context, and "cytoskeleton" to describe the polymer systems, when neither the cytosol nor cytoskeleton are the cytoplasmic compartment. Rather, they are operational descriptions of, respectively, what remains after centrifugation of disrupted cells or after extraction of cells with buffers containing non-ionic detergents. The title of Schliwa's wellproduced book perpetuates this unsatisfactory terminology, though the pedantically-minded are appeased in a short, but useful, chapter on the cytoplasm towards the end.

As its title suggests, the book is restricted largely to the morphological and biochemical properties of microtubules, actin filaments and intermediate filaments. Even so the relevant literature is enormous, and Schliwa's bias towards the properties of filaments in higher animal cells, although reflecting the emphasis of interest in the field, is not really appropriate for the intended audience of nonspecialists.

In writing a book such as this, difficult choices also have to be made in coping with subject matter which ranges freely from the phenomenological to the biophysical. These problems are compounded by uncertainties over the functional significance for cell behaviour of identified proteins, and even of the filaments themselves. Schliwa has chosen to divide his material between two sections, one on components and the other on interactions. The result is a rather arbitrary

- The third volume in the series of special issues of the journal Nucleic Acids Research, The Applications of Computers to Research on Nucleic Acids, has been published by IRL Press. Editors are D. Söll and R.J. Roberts, price is pbk $£ 35, \$ 63$. The previous volume was reviewed in Nature 309, 648 (1984). allocation of, for example, actin-binding proteins to different chapters, depending on how the author perceives their primary function. The text is thus rather bitty, which detracts from its value as an introduction to the field, as does the incomprehensible absence of any serious discussion (or illustrations) of myofibrils, the cleavage furrow, the mitotic spindle or cilia and flagella. Less serious are the large number of typographical errors and occasionally idiosyncratic prose, for which the publishers must take some responsibility.

\section{Past differences}

\section{Martin Welch}

The English Settlements. By J.N.L. Myres. Clarendon:1986. Pp.248. £15, $\$ 24.95$.

IT Is now 50 years since Collingwood and Myres published their classic English history textbook, not superseded until the late 1960 s by Frere's Britannia (Routledge and Kegan Paul, 1967) for Roman Britain and Myres's own Anglo-Saxon Pottery and the Settlement of England (Clarendon, 1969). This time the Anglo-Saxon settlements have been treated to a separate volume in the Oxford History of England series. Does it match the authority of his 1936 chapters? I think not, for though Myres has made valiant efforts to catch up with the current literature, in essence he presents again the views he established in the $1950 \mathrm{~s}$ and $1960 \mathrm{~s}$.

His discussions of the literary sources show him to be out of touch with recent work on source criticism undertaken by David Dumville and others. Archaeology has a more crucial role to play with so little written material, but Myres and I stand poles apart in our interpretation of the same evidence. Myres emphasizes the presence of Germans, including Saxons, in Late Roman Britain, seeing an unbroken continuity to independent AngloSaxon rule. In my opinion, however, there was a marked discontinuity between the collapse of the Roman economy with its material culture $c$. AD 400 and the subsequent foundation of Early Anglo-Saxon settlements, usually represented by their cemeteries. It seems strange to me that Myres can recognize the contrast with Gaul, where Roman towns and villa estates survived under Merovingian Frankish rule and the situation in Britain, where they did not, yet press on with what seems to me at best an ephemeral case for archaeological continuity from Roman Britain to Saxon England.

He believes that the Saxon Shore (litus Saxonicum), a Late Roman coastal defence chain stretching from the Wash to Portsmouth, was so named because
Work up to about the last quarter of 1984 is covered, with references in an excellent bibliography at the end. Although the book's usefulness as an introduction to cytoplasmic filament systems is compromised by its omissions, it will be valued by most cell biologists and students of the cytoplasm for its conscientious coverage of the morphological, and to a lesser extent biochemical, literature.

Peter Sheterline is a Lecturer in the Department of Medical Cell Biology, University of Liverpool, Liverpool L693BX, UK.

Saxons were settled along it by the Romans in the fourth century, if not earlier. Yet the Gothic bank (ripa Goth$i c a$ ) on the Danube was a Roman defence against the Goths, not a zone in which they were settled, so why should the Saxon Shore be different? Myres invented the concept of Romano-Saxon pottery in 1956 to support this view, but he disguises here how effectively John Gillam and William Roberts have demolished his case, though he provides references to both on pp. 92 and 89 respectively. Nor does he explain that his attribution of fourthcentury dates to some Anglo-Saxon pottery cremation urns is on the basis of analogies with pots of this date on the continent or in Scandinavia and is not confirmed by the presence of fourth-century Germanic metalwork in the English pots. Germanic pottery fashions were notoriously conservative and in my opinion all these urns probably belong in the fifth century, to a series of historically attested migrations across the North Sea. These migrations appear to have resulted from invitations by the British authorities to Saxons to fight for them as mercenaries against the threat of coastal invasion by the Picts of Scotland, effectively replacing a Roman army which had been withdrawn from Britain by AD 407. The Saxon mercenaries subsequently declared independence and founded settlements, which often developed into kingdoms.

Myres has an established expertise with Anglo-Saxon pottery, but his dating and discussion of Late Roman and AngloSaxon metalwork is often inaccurate and misleading. Thus his discussion of Quoit Brooch Style metalwork does not even mention the Mucking Grave 117 belt set, the only datable example, which was manufactured in the first quarter of the fifth century.

In a textbook intended not for archaeologists, but for history students (p.xxiii), the author has a duty to make his readers aware that radical alternative interpretations of the evidence have been published. In this Myres fails.

Martin Welch is a Lecturer in Medieval Archaeology in the Department of History, University College London, Gower Street, London $W C I E 6 B T, U K$ 